\title{
ASPEK HUKUM PENCEGAHAN DAN PENANGGULANGAN KORUPSI MELALUI PENDIDIKAN ANTIKORUPSI DI PERGURUAN TINGGI KHUSUSNYA DI UNIVERSITAS NEGERI JAKARTA
}

\author{
Oleh: Martini* \& Efridani Lubis*
}

\begin{abstract}
Although Indonesia has long history fighting corruption since its independence, however the fighting has not given positive resulted yet. The corruption cases is increasing from one rezim to another, even after reformation era which put its based movement toward fighting corruption. This phenomena drive many Indonesian people, experts, and scholars to evaluate the essence of fighting such bad behaviour either from culture, legal, and education perspective. Scholars suggested that the effective way of fighting the corruption is in preventive scheme rather in represive one. In this sense, it is education that could give great impact to build anti corruption character. The challenge in formulating such system in higher education not only due to the material or the subject given to the students, but also the method that need different approach to make sure that the needed character has been developed well.
\end{abstract}

Key Words: Anti-corruption, higher education, laws.

\section{A. Pendahuluan}

Seiring dengan bergulirnya reformasi di Indonesia pada tahun 1998, harapan akan kehidupan berbangsa dan bernegara yang lebih baik turut pula menguat dengan fokus pada ditinggalkannya praktek-praktek yang merugikan kehidupan berbangsa dan bernegara pada masa lalu, terutama praktek korupsi. Namun ternyata, harapan itu masih jauh dari kenyataan; dari beberapa data yang diperoleh mengenai pergerakan korupsi di Indonesia menunjukkan trend yang meningkat dari tahun ke tahun; bahkan sampai dengan tahun 2010 yang lalu. Menurut Indonesia Corruption Watch (ICW) (Kompas.com 2014), kasus korupsi di Indonesia terus meningkat, baik dari segi orang dan jumlah uang yang terlibat di dalamnya. Selain itu, beragamnya latar belakang pihak yang terlibat pun semakin luas; tidak terbatas hanya kalangan pengguna anggaran dan belanja negara, namun juga semakin banyak pihak swasta yang terlibat dalam kasus-kasus tersebut, sebagaimana terlihat dalam tabel berikut:

Tabel 1: Perkembangan Kasus Korupsi di Indonesia

\begin{tabular}{|c|c|c|c|}
\hline Tahun & $\begin{array}{c}\text { Jlh } \\
\text { Kasus }\end{array}$ & $\begin{array}{c}\text { Jlh Uang } \\
\text { (trilliun) }\end{array}$ & Pelaku \\
\hline 2009 & 86 & 1,7 & 217 \\
\hline 2010 & 176 & 2,102 & 441 \\
\hline
\end{tabular}

Sumber: Indonesia Corruption Watch, 2010

*Dosen Program Studi Pendidikan Ilmu Pengetahuan Sosial, Fakultas Ilmu Sosial Universitas Negeri Jakarta

*Dosen Fakultas Hukum Universitas Assyafiiyah Jakarta 


\begin{abstract}
Pengukuran tingkat korupsi Indonesia juga dapat dilihat dari angka Indeks Persepsi Korupsi (IPK). Pada tahun
\end{abstract} 2010, angka IPK Indonesia berada pada 2,8 atau di peringkat ke 110 dari 178 negara yang disurvei. Nilai ini sama persis dengan tahun sebelumnya. Nilai ini jauh berada di bawah Singapura yang skornya 9,3 dan merupakan negara dengan IPK tertinggi di Asean; masih lebih rendah dari Malaysia $(4,4)$, dan sedikit lebih tinggi dari Vietnam $(2,7)$ dan Timor Leste $(2,5)$. Berkaitan dengan hal ini, Presiden Susilo Bambang Yudhoyono berkeinginan untuk mencapai skor IPK Indonesia 5,0 pada tahun 2015.

Namun demikian, jumlah tindakan korupsi tidak dapat diwakili oleh kasuskasus di atas; lebih banyak lagi kasus-kasus korupsi yang tidak terungkap ataupun tidak sadar dilakukan oleh masyarakat Indonesia secara luas. Terakhir issu mengenai dibiarkannya siswa menyontek dalam Ujian Nasional tahun 2012 juga merupakan tindakan tidak terpuji yang bisa dikategorikan sebagai cikal bakal korupsi yang lebih besar. Oleh karena itu, tindakan korupsi lebih merupakan pilihan individu daripada sistem yang tidak bisa dihindari; hal ini berkaitan dengan karakter dan kepribadian orang yang terlibat; yang jika secara umum dapat dikatakan sebagai orang-orang yang berkesempatan mendapatkan pendidikan yang baik.
Pendidikan sebagai sarana untuk mentransfer nilai-nilai kebaikan dan ketrampilan hidup kelihatannya belum bisa berjalan dengan baik; karena masih menghasilkan peserta didik yang mampu melakukan tindakan-tindakan tidak terpuji di atas. Mata pelajaran atau mata kuliah yang paling dekat dengan pembentukan karakter dan kepribadian baik ini dalam kurikulum di tingkat sekolah dasar sampai dengan perguruan tinggi adalah pendidikan kewarganegaraan.

Menurut Pasal 37 ayat (2) UndangUndang Nomor 20 Tahun 2003 Tentang Sistem Pendidikan Nasional, pendidikan kewarganegaraan merupakan muatan wajib dalam kurikulum pendidikan tinggi. Selanjutnya dalam Pasal 9 ayat (2) Peraturan Pemerintah Nomor 19 Tahun 2005 Tentang Standar Nasional Pendidikan, disebutkan bahwa dalam kurikulum pendidikan tinggi wajib memuat mata kuliah pendidikan kewarganegaran selain pendidikan agama, Bahasa Indonesia, dan Bahasa Inggris.

Sebagai mata kuliah wajib, keempat mata kuliah di atas dikelompokkan pada pengembangan kepribadian. Menurut Pasal 1 Keputusan Direktur Jenderal Pendidikan Tinggi Departemen Pendidikan Nasional Nomor 43/DIKTI/Kep/2006 Tentang Rambu-Rambu Pelaksanaan Kelompok Matakuliah Pengembangan Kepribadian di Perguruan Tinggi ditegaskan bahwa pendidikan kewarganegaraan sebagai mata 
kuliah pengembangan kepribadian merupakan sumber nilai dan pedoman dalam upaya memantapkan kepribadiaan mahasiswa sebagai manusia Indonesia seutuhnya.

Kepribadian manusia Indonesia seutuhnya sebagaimana dimaksud di atas, diterjemahkan pada pencapaian kompetensi dasar pendidikan kewarganegaraan, yang menurut Pasal 3 ayat (2) b menjadi ilmuwan dan profesional yang memiliki rasa kebangsaan dan cinta tanah air, demokratis yang berkeadaban, menjadi warga negara yang memiliki daya saing, berdisiplin, dan berpartisipasi aktif dalam membangun kehidupan yang damai berdasarkan sistem nilai Pancasila.

Diktum Kesebelas angka 7 Instruksi Presiden Nomor 5 Tahun 2004 Tentang Percepatan Pemberantasan Korupsi menugaskan Menteri Pendidikan Nasional menyelenggarakan pendidikan yang berisikan substansi penanaman semangat dan perilaku anti korupsi pada setiap jenjang pendidikan baik formal dan non formal.

Melihat fenomena di atas, maka perlu melakukan kajian untuk mengintegrasikan sikap anti korupsi di kalangan mahasiswa terutama; yang merupakan calon-calon pemimpin masa depan yang akan menjadi pengambil keputusan penggunaan anggaran serta memiliki akses terhadap anggaran dimaksud, melalui kurikulum yang lebih jelas target capaian karakter yang diinginkan.

\section{B. Pembahasan}

\section{B.1. Pengertian Korupsi}

Korupsi berasal dari kata "corruption" (Latin) yang berarti kebusukan, keburukan, kebejatan, ketidakjujuran, dapat disuap, tidak bermoral, penyimpangan dari kesucian (Webster Student Dictionary 1960:233). Menurut kamus besar Indonesia, pengertian korupsi adalah kejahatan, kebusukan, dapat disuap, tidak bermoral, kebejatan dan ketidakjujuran. Pengertian lainnya adalah 'perbuatan yang buruk seperti penggelapan uang, penerimaan uang sogok, dan sebagainya (Poerwadarminta 1976: 312).

Merujuk pada istilah yang digunakan oleh Malaysia 'resuah' yang diambil dari bahasa Arab 'risywah' juga berarti korupsi. Pengertian istilah ini berarti pemberian yang diberikan oleh seseorang kepada hakim atau lainnya untuk memenangkan perkaranya dengan cara yang tidak dibenarkan atau untuk memperoleh kedudukan (Andi Hamzah 2002:45). Berdasarkan Surat Al Maidah ayat 42, semua ulama sepakat mengharamkan risywah yang terkait dengan pemutusan hukum; bahkan menurut sebagian besar ulama, perbuatan ini merupakan dosa besar. Jadi risywah 
(suap menyuap) identik dengan memakan barang yang diharamkan oleh Allah SWT, termasuk perbuatan mencari suap, menyuap dan menerima suap; begitu juga orang yang menjadi perantara (mediator) antara penyuap dan yang disuap (Dirjen Pendidikan Tinggi 2011:6).

Dalam kerangka hukum, Pasal 2 Undang-Undang Nomor 31 Tahun 1999 Tentang Pemberantasan Tindak Pidana Korupsi, korupsi diartikan sebagai perbuatan memperkaya diri sendiri atau orang lain atau suatu korporasi secara melawan hukum yang dapat merugikan keuangan negara atau perekonomian negara. Perbuatan memperkaya diri sendiri atau orang lain yang dapat merugikan keuangan negara atau perekonomian negara dikategorikan sebagai tindak pidana, bukan perbuatan perdata. Pengkategorian demikian dikarenakan bahwa korupsi dinilai sangat merugikan keuangan negara atau perekonomian negara yang melibatkan kontribusi semua komponen bangsa berupa pajak sehingga dapat menghambat pembangunan nasional' sehingga harus diberantas dalam rangka mewujudkan masyarakat adil dan makmur berdasarkan Pancasila dan UUD 1945.

Upaya

pencegahan

dan pemberantasan korupsi seharusnya dilakukan dalam seluruh aspek kehidupan: politik, hukum, sosial, dan terutama pendidikan. Secara politik, upaya pencegahan dan pemberantasan korupsi dilakukan dengan menegakkan integritas serta pemilihan para penyelenggara negara yang berpihak pada penyelenggaraan tata pemerintahan dan tata kelola yang bersih dan transparan.

Secara hukum, upaya pencegahan dan penanggulan korupsi adalah dengan menerapkan sanksi yang berat untuk setiap orang yang secara melawan hukum melakukan perbuatan memperkaya diri sendiri atau orang lain atau suatu korporasi yang dapat merugikan keuangan negara atau perekonomian negara dimaksud. Menurut Undang-Undang Nomor 31 Tahun 1999, sanksi tersebut berupa pidana penjara, pidana penjara seumur hidup atau bahkan pidana mati untuk keadaan tertentu. Pidana penjara ancamannya mulai dari 4 (empat) tahun sampai dengan 20 (dua puluh) tahun. Di samping itu, pelaku juga dapat dikenakan denda mulai dari 200 juta rupiah sampai dengan 1 milyar rupiah.

Selanjutnya secara sosial, upaya pencegahan dan pemberantasan korupsi dilakukan dengan melibatkan partisipasi masyarakat secara luas: mulai dari aktif dalam menyebarkan nilai-nilai anti-korupsi melalui gerakan sosial dan lembaga swadaya masyarakat sampai dengan berperan aktif dalam upaya penegakan hukum sebagai pelapor aktif dan sebagai saksi yang dilindungi secara hukum. 
Namun demikian, upaya-upaya di atas tidak bisa efektif jika sikap anti-korupsi tidak ditumbuhkan sedini mungkin, secara formal maupun non formal. Pendidikan merupakan salah satu elemen efektif yang dapat mengajarkan dan mengembangkan sikap anti-korupsi secara terstruktur dan efektif. Kesempatan untuk memperkaya diri sendiri yang merugikan keuangan negara sangat dekat dengan para penyelenggara negara yang menggunakan uang negara dalam melaksanakan tugas pokok dan fungsinya sehari-hari. Sebagian besar dari penyelenggara negara ini adalah lulusan perguruan tinggi; berkesempatan untuk mengerti akan bahaya dan dampak korupsi serta konsekuensinya jika diberi kesempatan untuk itu. Selama ini pendidikan antikorupsi telah dilakukan secara formal; namun kelihatannya upaya tersebut belum efektif, karena terbukti angka statistik tentang korupsi di Indonesia semakin meningkat dari tahun ke tahun sejak reformasi bergulir. Oleh karena itu, upaya pencegahan dan penanggulangan korupsi melalui pendidikan perlu dirumuskan secara formal agar dampak dan perilaku sikap antikorupsi bisa lebih terukur secara ilmiah.

\section{B.2. Pengaturan AntiKorupsi di Indonesia}

Jika diamati pada tataran peraturan perundang-undangan, Indonesia memiliki peraturan berkenaan dengan pemberantasan korupsi yang cukup beragam, namun peraturan tersebut hanya berkenaan dengan tindakan represif yang efektivitasnya pun belum memadai.

1. Peraturan Nomor PRT/PM/06/1957 dikeluarkan oleh Penguasa Militer Angkatan Darat dan berlaku untuk daerah kekuasaan Angkatan Darat

2. Peraturan Penguasa Militer Nomor PRT/PM/08/1957

3. Peraturan Penguasaan Militer Nomor PRT/PM/011/1957

4. Undang-Undang Nomor 24/Prp/Tahun 1960 tentang Pengusutan, Penuntutan, dan Pemeriksaan Tindak Pidana Korupsi

5. Peraturan Pemerintah Pengganti Undang-Undang Nomor 24 Tahun 1960 tentang Pengusutan, Penuntutan, dan Pemeriksaan Tindak Pidana Korupsi

6. Undang- Undang Nomor 3 Tahun 1971 (LNRI 1971-19, TNLRI 2958) tentang Pemberantasan Tindak Pidana Korupsi

7. Undang- Undang Nomor 31 Tahun 1999 (LNRI 1999-40, TNLRI 387), tentang Pemberantasan Tindak Pidana Korupsi

8. Undang-Undang Nomor 20 Tahun 2001 (LNRI 2001-134， TNLRI 4150), tentang Perubahan atas UndangUndang Nomor 31 Tahun 1999 tentang Pemberantasan Tindak Pidana Korupsi

9. Undang- Undang Nomor 30 Tahun 2002 (LNRI 2002-137. TNLRI 4250) 
tentang Komisi Pemberantasan Tindak

Pidana Korupsi.

10. Undang-Undang Nomor 7 Tahun 2006 tentang Pengesahan 'United Nations Convention Against Corruption, 2003

11. Kitab Undang- Undang hukum Pidana (KUHP) di atas adalah Pasal 103 KUHP.
Dari kesebelas

peraturan perundang-undangan di atas, perkembangan pengaturan pemberantasan korupsi dapat digambarkan sebagai berikut:

\begin{tabular}{|c|c|c|c|}
\hline Perihal & UU No. 3/1971 & UU No. 31/ 1999 & UU No. 30/2002 \\
\hline Pengertian & $\begin{array}{l}\text { memperkaya diri sendiri } \\
\text { atau orang lain, atau } \\
\text { suatu Badan, } \\
\text { yang secara langsung } \\
\text { atau tidak langsung } \\
\text { merugikan } \\
\text { keuangan negara dan atau } \\
\text { perekonomian negara, } \\
\text { atau patut } \\
\text { diketahui atau bahwa } \\
\text { disangka olehnya baha } \\
\text { perbuatan merugikan } \\
\text { tersebut at nau } \\
\text { keuangan negara atau } \\
\text { perekonomian } \\
\text { negara; }\end{array}$ & $\begin{array}{l}\text { secara melawan } \\
\text { hukum melakukan } \\
\text { perbuatan } \\
\text { memperkaya diri } \\
\text { sendiri atau orang } \\
\text { lain atau suatu } \\
\text { korporasi yang dapat } \\
\text { merugikan keuangan } \\
\text { negara } \\
\text { atau perekonomian } \\
\text { negara }\end{array}$ & $\begin{array}{l}\text { Tindak Pidana Korupsi } \\
\text { adalah tindak pidana } \\
\text { sebagaimana } \\
\text { dimaksud dalam } \\
\text { Undang-Undang } \\
\text { Nomor } 31 \text { Tahun } 1999 \\
\text { tentang } \\
\text { Pemberantasan Tindak } \\
\text { Pidana Korupsi } \\
\text { sebagaimana telah } \\
\text { diubah dengan } \\
\text { Undang-Undang } \\
\text { Nomor 20 Tahun } 2001 \\
\text { tentang atas } \\
\text { Perubahan } \\
\text { Undang-Undang } \\
\text { Nomor 31 Tahun } 1999 \\
\text { tentang Pemberantasan Tindak } \\
\text { Pidana Korupsi. }\end{array}$ \\
\hline & $\begin{array}{l}\text { memberi hadiah atau } \\
\text { janji kepada pegawai } \\
\text { negeri }\end{array}$ & \begin{tabular}{|lr}
\multicolumn{2}{l}{ menyalahgunakan } \\
kewenangan, \\
kesempatan atau \\
sarana yang ada \\
padanya & karena \\
jabatan atau & kedudukan yang \\
dapat merugikan & keuangan negara atau \\
perekonomian negara
\end{tabular} & \\
\hline & $\begin{array}{l}\text { menerima pemberian atau } \\
\text { janji tanpa alasan yang } \\
\text { wajar dan tanpa } \\
\text { melaporkan pemberian }\end{array}$ & $\begin{array}{l}\text { memberi hadiah atau } \\
\text { janji kepada pegawai } \\
\text { negeri dengan } \\
\text { mengingat }\end{array}$ & \\
\hline
\end{tabular}




\begin{tabular}{|l|l|l|l|}
\hline & $\begin{array}{l}\text { atau janji tersebut kepada } \\
\text { yang berwajib }\end{array}$ & $\begin{array}{l}\text { kekuasaan atau } \\
\text { wewenang yang } \\
\text { melekat pada jabatan } \\
\text { atau kedudukannya }\end{array}$ & \\
\hline Pengadilan & Pengadilan Negeri & Pengadilan Negeri & Penyidikan: KPK \\
\hline Sanksi & $\begin{array}{l}\text { hukuman penjara seumur } \\
\text { hidup atau penjara } \\
\text { selama-lamanya 20 tahun } \\
\text { dan/atau denda setinggi- } \\
\text { tingginya 30 (tiga puluh) } \\
\text { juta rupiah. }\end{array}$ & $\begin{array}{l}\text { pidana penjara } \\
\text { dengan penjara } \\
\text { seumur hidup atau } \\
\text { pidana penjara paling } \\
\text { singkat 4 tahun dan } \\
\text { paling lama 20 tahun } \\
\text { dan denda paling } \\
\text { sedikit Rp. 200 juta } \\
\text { paling banyak Rp. 1 } \\
\text { Milyar }\end{array}$ & \\
\hline
\end{tabular}

Dari tabel di atas, terlihat bahwa sistem pemberantasan korupsi berkembang signifikan setelah era reformasi pada tahun 1997. Hal pertama yang dikembangkan adalah memperluas definisi korupsi yang meliputi pula menyalahgunakan wewenang untuk memperkaya diri sendiri atau golongan. Hal lainnya adalah meningkatkan ancaman hukumannya berupa denda yang dipertinggi nilai denda pengganti pidananya. Pada tahun 2002, perubahan yang lebih besar lagi telah ditetapkan, berupa membentuk lembaga penyelidik dan penyidik khusus untuk memberantas korupsi, yaitu Komisi Pemberantasan Korupsi (KPK).

\section{B.3. Penyebab Terjadinya Korupsi}

Walaupun korupsi ditengarai sesuatu yang melekat pada perkembangan masyarakat baik di tingkat dunia maupun di tingkat Indonesia, namun beberapa pakar berusaha mengidentifikasi penyebab terjadinya korupsi sehingga upaya pemberantasannya dapat dilaksanakan secara efektif pada gilirannya. Menurut Ali Rokhmad (2013:23-35) beberapa penyebab atau sumber terjadinya korupsi antara lain:

1. Kelemahan kepemimpinan

2. Kelemahan rasa etis dan agama

3. Rendahnya kualitas pendidikan (moral)

4. Kemiskinan

5. Penegakan hukum yang lemah

\section{B.4. Upaya Pencegahan dan}

\section{Penanggulangan Korupsi}

Menyadari bahaya massif perilaku korupsi, para pemimpin negara sejak awal kemerdekaan sudah memiliki pemikiran untuk memberantas korupsi. Pertumbuhan dan perkembangan sikap anti korupsi di Indonesia tidak terlepas dari muncul dan berkembangnya sikap korupsi di tanah air. 
Korupsi pada awalnya muncul sebagai budaya dan kebiasaan di kalangan masyarakat. Literatur menunjukkan bahwa kebiasaan untuk menyelesaikan konflik di antara para pejabat pada zaman kerajaan kuno (Mataram, Majapahit, Singosari, Demak, Banten, dll) dengan motif memperkaya diri sendiri telah menjadi faktor utama kehancuran kerajaan-kerajaan tersebut. Menariknya, kebiasaan untuk menyenangkan atasan telah pula terstruktur dalam birokrasi dengan dibentuknya 'abdi dalem' yang secara alamiah memang akan bersikap 'asal bapak/ibu senang' untuk mempertahankan posisinya dalam kerajaan.

Secara eksternal, budaya korupsi terlihat dari budaya 'upeti' yang merupakan sesembahan rakyat kecil kepada Raja sebagai wujud ketertundukan rakyat terhadap kekuasaan raja pun membawa dampak dalam perkembangan budaya korupsi di Indonesia. Ketika Belanda menjajah Nusantara (1800-1942) minus penjajahan Inggris (1811-1816), budaya upeti tersebut tetap diteruskan Belanda. Warga yang ditunjuk oleh Belanda sebagai pegawai mereka untuk mengumpulkan upeti dari rakyat menggunakan kesempatan itu untuk memperkaya diri mereka sendiri; baik dari kalangan pejabat Belandanya sendiri maupun dari pegawai pribumi yang bekerja untuk Belanda. Di samping itu, sudah menjadi rahasia umum jika ingin menjadi pegawai Belanda, apakah sebagai demang (lurah), tumenggung (setingkat bupati/gubernur) atau jabatan-jabatan lainnya, harus ada uang pelicin agar dapat menduduki jabatan-jabatan tersebut. Tradisi korupsi dan kolusi ini terbawa terus sampai pada zaman kemerdekaan dan zaman modern sekarang ini.

Sebagian kalangan menyebutkan bahwa budaya korupsi dan kolusi ini bisa terus berkembang pada zaman Orde Lama dan Orde Baru karena kepemimpinan yang cenderung otoriter dan anti kritik, namun pada Era Reformasi sekarang ini yang lebih demokratis dan terbuka, praktek korupsi dan kolusi tersebut terus berkembang adanya bahkan meluas dan massif sifatnya. Jika pada era sebelumna korupsi terutama dilakukan oleh elit politik dan/atau pemerintahan saja, namun pada Era Reformasi ini, korupsi tersebut dilakukan oleh hampir seluruh penyelenggara negara yang juga dikenal dengan korupsi berjamaah. Oleh karenanya tidaklah mengherankan jika Indonesia masuk salah satu negara terkorup di dunia saat ini.

Pada zaman pemerintahan Orde Lama, usaha Presiden Soekarno untuk memberantas korupsi di Indonesia cukup serius, ditandai dengan didirikannya dua lembaga setara Komisi Pemberantasan Korupsi (KPK) saat ini, yaitu Panitia Retooling Aparatur Negara (Paran) dan 
Operasi Budhi. ini maka dikeluarkanlah Undang-Undang Nomor 18 Tahun 1961 Tentang Ketentuan Pokok Kepegawaian dan pembentukan Badan Administrasi Kepegawaian Negara (BAKN) dan Peraturan Presiden Nomor 5 Tahun 1962 Tentang Pokok-Pokok Organisasi Aparatur Pemerintah Negara Tingkat Tertinggi. Namun gerakan ini dinilai tidak berhasil karena para pejabat kala itu mampu membubarkan lembaga ini.

Karena gerakan ini dinilai tidak berhasil, pada tahun 1963 Sekalipun masih banyak hambatan dalam pemberantasan korupsi tersebut, namun tercatat dalam waktu 3 bulan sejak berjalannya Operasi Budhi, lembaga ini dapat menyelamatkan keuangan negara sebesar Rp 11 miliar. Namun lagi-lagi karena alasan politis, karena dianggap mengganggu prestise Presiden, gerakan ini pun akhirnya dihentikan. Sebagai gantinya dibentuklah Komando Tertinggi Retooling Aparatur Revolusi (KONTRAR) dengan Keppres Nomor 98 Tahun 1964 yang merupakan kelanjutan tugas PARAN yang sebelumnya telah dibubarkan. Namun karena mengalami stagnasi akhirnya lembaga ini pun mati suri.

Pada Orde Baru, kesadaran bahwa korupsi merupakan penyakit yang harus ditangani dengan serius cukup kuat, hal ini terlihat pidato Soeharto pada tahun 1967 yang menyalahkan rezim Orde Lama yang tidak mampu memberantas korupsi sehingga segala kebijakan ekonomi dan politik berpusat di Istana. Untuk mewujudkan kerisauannya tersebut, Soeharto kemudian membentuk Tim Pemberantasan Korupsi (TPK) yang diketuai Jaksa Agung. Lagi-lagi lembaga ini mengalami kebuntuan, yang kemudian digantikan dengan Komite Empat beranggotakan tokoh-tokoh tua yang dianggap bersih dan berwibawa seperti Prof Johannes, IJ Kasimo, Mr Wilopo dan A Tjokroaminoto. Tugas mereka yang utama adalah membersihkan antara lain Departemen Agama, Bulog, CV Waringin, PT Mantrust, Telkom, dan Pertamina. Namun kornite ini hanya "macan ompong" karena hasil temuannya tentang dugaan korupsi di Pertamina tak direspon pemerintah.

Setelah era reformasi bergulir, usaha pemberantasan korupsi lebih digiatkan karena tuntutan masyarakat. Dengan disahkannya Undang-Undang Nomor 28 Tahun 1999 Tentang Penyelenggaraan Negara yang Bersih, dan Bebas dari Korupsi, Kolusi dan Nepotisme, didirikanlah Komisi Pengawas Kekayaan Pejabat Negara (KPKPN). Bersamaan dengan itu, disahkan pula Undang-Undang Nomor 31 Tahun 1999 Tentang Pemberantasan Tindak Pidana Korupsi. 
Kemudian pada tahun yang sama dibentuklah Komisi Pemberantasan Korupsi berdasarkan Undang-Undang Nomor 30 Tahun 2002 tentang Komisi Pemberantasan Tindak Pidana Korupsi, sebuah lembaga pemberantasan korupsi yang paling berpengaruh hingga hari ini.

\section{B.5. Pendidikan Karakter dan Pencegahan dan Penanggulangan Korupsi}

Menurut Undang-Undang Nomor 20 Tahun 2003 Tentang Sistem Pendidikan Nasional, pendidikan pengembangan karakter atau pengembangan kepribadian di perguruan tinggi antara lain adalah pendidikan kewarganegaran. Pendidikan kewarganegaraan merupakan mata kuliah wajib di pendidikan tinggi. Pendidikan kewarganegaraan sebagai mata kuliah pengembangan kepribadian menurut Pasal 1 Keputusan Direktur Jenderal Pendidikan Tinggi Departemen Pendidikan Nasional Nomor 43/DIKTI/Kep/2006 Tentang Rambu-Rambu Pelaksanaan Kelompok Matakuliah Pengembangan Kepribadian di Perguruan Tinggi merupakan sumber nilai dan pedoman dalam upaya memantapkan kepribadiaan mahasiswa sebagai manusia Indonesia seutuhnya. Pencapaian pribadi dan manusia Indonesia seutuhnya diterjemahkan menjadi ilmuwan dan profesional yang memiliki rasa kebangsaan dan cinta tanah air, demokratis yang berkeadaban, menjadi warga negara yang memiliki daya saing, berdisiplin, dan berpartisipasi aktif dalam membangun kehidupan yang damai berdasarkan sistem nilai Pancasila.

Sementara itu, menurut UndangUndang Nomor 31 Tahun 1999 tentang Pemberantasan Tindak Pidana Korupsi disebutkan bahwa karakter korupsi adalah segala upaya memperkaya diri sendiri atau golongan atau korporasi secara melawan hukum yang menimbulkan kerugian keuangan negara dan perekonomian negara. Dengan demikian unsur karakter yang diinginkan berdasarkan UndangUndang Nomor 31 Tahun 1999 adalah pribadi yang tidak memiliki niat untuk memperkaya diri sendiri atau golongan atau korporasi secara melawan hukum. Pengembangan karakter tidak memiliki niat untuk memperkaya diri sendiri kelihatannya lebih kompleks dari sasaran kepribadian yang diinginkan dan ditargetkan oleh Keputusan Direktur Jenderal Pendidikan Tinggi Departemen Pendidikan Nasional Nomor 43/DIKTI/Kep/2006.

Karena itu, perlu diidentifikasi unsur-unsur pembentuk karakter yang tidak memiliki niat untuk memperkaya diri sendiri atau golongan atau korporasi secara melawan hukum. Beberapa karakter yang 
diharapkan dapat mendorong pembentukan sikap anti-korupsi melalui perspektif hukum dimaksud antara lain:

1. Mampu berpikir secara kritis, rasional, dan kreatif dalam menanggapi isu-isu korupsi secara objektif dan ilmiah.

2. Berpartisipasi secara aktif dan bertanggung jawab dan bertindak secara cerdas dalam kegiatan bermasyarakat, berbangsa, dan bernegara, serta anti korupsi.

3. Berkembang secara positif dan demokratis untuk membentuk diri berdasarkan karakter masyarakat Indonesia agar dapat hidup bersama dengan bangsa-bangsa lainnya.

4. Mampu berinteraksi dengan bangsa lain dalam percaturan dunia secara langsung atau tidak langsung dengan memanfaatkan teknologi informasi dan komunikasi.

5. Mampu memahami batasan-batasan perbuatan korupsi sesuai dengan peraturan perundang-undangan yang berlaku.

Kedua karakter yang dikembangkan di atas perlu diharmonisasikan dan diintegrasikan secara baik sehingga dapat diterapkan dalam kurikulum pendidikan kewarganegaraan di perguruan tinggi.
Integrasi sikap anti korupsi dalam mata kuliah pendidikan kewarganegaraan berarti dalam perspektif pendidikan sekaligus hukum. Pendidikan anti korupsi dalam perspektif pendidikan diartikan sebagai usaha sadar dan terencana untuk mewujudkan proses belajar - mengajar yang kritis terhadap nilai-nilai anti korupsi. Dalam proses tersebut, pendidikan anti korupsi bukan sekedar media bagi transfer pengetahuan (kognitif), namun juga menekankan pada upaya pembentukan karakter (afektif), dan kesadaran moral dalam melakukan perlawanan (psikomotorik), terhadap perilaku korupsi. Namun demikian, pengembangan sikap anti korupsi bernuansa pendidikan dimaksud tidak akan efektif jika tidak memahami karakter dan aspek hukum anti korupsi di dalamnya. Oleh karena itu, aspek hukum mengenai korupsi serta pencegahan dan penanggulangannya harus pula dipahami dengan baik. Dengan demikian, hasil identifikasi makna pencegahan dan penanggulangan korupsi secara regulasi kemudian diturunkan menjadi nilai yang dapat diukur menurut metode pendidikan.

Salah satu karakter yang ingin dikembangkan melalui kurikulum pendidikan anti korupsi berdasarkan pembelajaran dari perihal di atas adalah kemampuan peserta didik untuk mengidentifikasi akar masalah dalam 
setiap tindak korupsi sehingga dapat diantisipasi pencegahannya sedini mungkin; tidak melulu melalui pendekatan represif yang bisa berdampak buruk tidak hanya pada pelaku, terlebih-lebih kepada anggota keluarga pelaku.

\section{B.6. Karakter, Nilai, Sikap Membangun} Budaya Anti Korupsi dalam Pendidikan Anti Korupsi

Pendidikan antikorupsi pada dasarnya adalah penanaman dan penguatan nilai-nilai dasar yang diharapkan mampu membentuk sikap antikorupsi pada diri peserta didik. Ada beberapa pemikiran mengenai karakter yang perlu dibangun dan dikembangkan agar sikap anti korupsi terbentuk dengan baik.

Pada tatanan regulasi, UndangUndang Nomor 20 Tahun 2003 Tentang Sistem Pendidikan Nasional, karakter yang ingin dicapai dari sistem pendidikan adalah peserta didik yang: (1) beriman dan bertaqwa kepada Tuhan Yang Maha Esa, (2) berakhlak mulia, (3) sehat, (4) berilmu, (5) cakap, (6) kreatif, (7) mandiri, (8) demokratis, dan (9) bertanggungjawab. Sekalipun karakter ini masih bersifat umum, namun pada prinsipnya karakter baik ini juga dapat menjadi karakter yang dapat menumbuhkan sikap anti korupsi.
Komisi Pemberantasan Korupsi juga mengembangkan sembilan nilai dasar yang perlu ditanamkan dan diperkuat melalui pelaksanaan pendidikan antikorupsi di sekolah, yaitu (1) jujur, (2) adil, (3) berani, (4) hidup sederhana, (5) tanggung jawab, (6) disiplin, (7) kerja keras, (8) hemat, dan (9) mandiri (Montessori, 295). Nilai-nilai ini sesungguhnya merupakan nilai-nilai yang hidup dalam masyarakat Indonesia sejak zaman dahulu, yang kemudian diakomodir dalam sistem nilai berbangsa dan bernegara, yaitu Pancasila.

Apabila merujuk kepada nilai-nilai dalam Pancasila, KPK juga memberikan penjabaran bagaimana karakter anti korupsi dirumuskan dari Pancasila sebagai berikut:

- Sila Pertama: Ketuhanan Yang Maha Esa: pemahaman dan implementasi nilai Sila Pertama yang benar akan menumbuhkan karakter etis; yaitu kesadaran mengenai yang benar dan yang salah, sehingga pada gilirannya dapat menolak godaan untuk berbuat korupsi.

- Sila Kedua: Kemanusiaan Yang Adil dan Beradab: pemahaman dan penerapan nilai Sila Kedua ini memunculkan karakter kematangan sosial; yaitu karakter yang berkaitan dengan hubungan dengan masyarakat 
luas. Dalam kategori ini termasuk karakter manusiawi, adil, dan beradab.

- Sila Ketiga dan Keempat: Persatuan Indonesia dan Kerakyatan Yang Dipimpin Oleh Hikmah Kebijaksanaan dalam

Permusyawaratan/Perwakilan:

pemahaman dan penerapan kedua Sila ini akan menumbuhkan karakter respek dan interdependensi berupa karakter kerjasama, saling menghormati, dan demokratis.

- Sila Kelima: Keadilan Sosial Bagi Seluruh Rakyat Indonesia: pemahaman dan penerapan Sila ini akan menumbuhkan karakter sinergis; yaitu menempatkan kepentingan bersama di atas kepentingan pribadi.

Karakter yang berupa watak, tabiat, akhlak, dan kepribadian yang terbetuk melalui proses internalisasi nilai kebajikan yang diyakini dan dijadikan pandangan dalam berpikir, bersikap dan berperilaku dalam kehidupan. Pengembangan karakter seseorang tidak dapat dilepaskan dari konteks kehidupan lingkungan sosial dan budaya setempat. Oleh karena itu, proses internalisasi nilai kebajikan ini menjadi fokus pengembangan kurikulum pendidikan anti korupsi.

Proses internalisasi menurut Budiningsih (2004:44), harus memperhatikan 4 hal, yaitu (1) pengertian atau pemahaman terhadap karakter integritas, (2) perasaan integritas, (3) tindakan integritas, dan (4) internalisasi nilai-nilai (keimanan, etika, dan moral). Keempat komponen tersebut sekaligus juga mencakup domain kognitif, afektif dan psikomotorik yang dicapai melalui materi dan metode pembelajaran yang tepat. Dengan demikian, perilaku anti korupsi merupakan karakter 'bentukan' yang memang direncanakan dengan seksama melalui proses internalisasi dimaksud. Oleh karena itu metode pembelajaran yang paling tepat untuk perilaku 'bentukan' tadi adalah metode planned behavior dari Fishbein dan Ajzen (1975)..

\section{B.7. Kurikulum Pendidikan Anti}

\section{Korupsi di Universitas Negeri Jakarta}

\section{yang Integratif}

Merespon perkembangan yang terjadi di tingkat internasional dan nasional, serta pendapat berbagai kalangan terkait, ditambah pertimbangan bahwa Universitas Negeri Jakarta adalah eks universitas berbasis pendidikan, maka sangatlah tepat jika UNJ mengambil tempat secara aktif dalam merumuskan kurikulum anti korupsi yang responsif dan integratif dengan permasalahan edukasi, sosial, dan politik bangsa. Merujuk pada penjelasan pada bagian terdahulu, inti dari pendidikan korupsi meliputi 
(1) pengetahuan tentang korupsi,

(2) pengembangan sikap anti korupsi,

(3) perubahan sikap menuju anti korupsi,

(4) perspektif moral, agama, dan sosial atas korupsi, dan

(5) perspektif internasional.
Pendidikan anti korupsi di UNJ diusulkan bermuatan 2 SKS dengan penjabarannya sebagai berikut:

\begin{tabular}{|c|c|c|}
\hline Pertemuan & Topik Bahasan & Lingkup Bahasan \\
\hline I & $\begin{array}{l}\text { Definisi dan Prinsip } \\
\text { Anti Korupsi }\end{array}$ & $\begin{array}{l}\text { Menjelaskan arti, makna, bentuk-bentuk dan perilaku } \\
\text { korupsi sehingga mahasiswa mampu membedakan dan } \\
\text { menganalisis perbuatan korupsi dan perilaku koruptif }\end{array}$ \\
\hline II & $\begin{array}{l}\text { Sejarah Korupsi di } \\
\text { Indonesia }\end{array}$ & $\begin{array}{l}\text { Menjelaskan sejarah korupsi di Indonesia sehingga } \\
\text { mahasiswa terbuka pikirannya akan bahaya korupsi } \\
\text { sejak bangsa ini berdiri }\end{array}$ \\
\hline III & $\begin{array}{l}\text { Masyarakat } \\
\text { Indonesia dan } \\
\text { Budaya Korupsi }\end{array}$ & $\begin{array}{l}\text { Menelaah secara kritis perilaku koruptif dari aspek } \\
\text { budaya Indonesia sehingga mahasiswa dapat } \\
\text { mengevaluasi kaitan budaya dengan perilaku koruptif } \\
\text { yang pada gilirannya mampu mengembangkan budaya } \\
\text { anti korupsi di zaman modern ini }\end{array}$ \\
\hline IV & $\begin{array}{l}\text { Faktor Penyebab } \\
\text { Korupsi }\end{array}$ & $\begin{array}{l}\text { Menjelaskan dan mendiskusikan faktor pendorong } \\
\text { terjadinya korupsi sehingga mahasiswa mampu } \\
\text { mengidentifikasi faktor internal dan eksternal } \\
\text { penyebab korupsi untuk menumbuhkan sikap anti } \\
\text { korupsi }\end{array}$ \\
\hline V & $\begin{array}{l}\text { Dampak Masif } \\
\text { Korupsi }\end{array}$ & $\begin{array}{l}\text { Menjelaskan dan mendiskusikan akibat sikap koruptif } \\
\text { sehingga mahasiswa mampu membangun rasa empati } \\
\text { bagi para korban tindakan korupsi }\end{array}$ \\
\hline VI & $\begin{array}{l}\text { Upaya } \\
\text { Pemberantasan } \\
\text { Korupsi }\end{array}$ & $\begin{array}{l}\text { Menjelaskan dan mendiskusikan berbagai upaya } \\
\text { pemberantasan korupsi sehingga dapat memilih } \\
\text { tindakan pencegahan korupsi yang paling tepat }\end{array}$ \\
\hline VII & UTS & \\
\hline VIII & $\begin{array}{l}\text { Berbagai Strategi } \\
\text { Pemberantasan } \\
\text { Korupsi (Perspektif } \\
\text { Hukum Pidana) }\end{array}$ & $\begin{array}{l}\text { Menjelaskan dan mendiskusikan pendekatan hukum } \\
\text { terhadap tindakan korupsi sehingga mahasiswa } \\
\text { mampu mengidentifikasi perilaku koruptif yang dapat } \\
\text { dikenai sanksi menurut hukum }\end{array}$ \\
\hline IX & Bedah Kasus I & $\begin{array}{l}\text { Menjelaskan dan mendiskusikan kasus korupsi yang } \\
\text { telah diproses di persidangan sehingga mahasiswa } \\
\text { memahami bagaimana seluk beluk terjadinya perilaku } \\
\text { koruptif dalam masyarakat }\end{array}$ \\
\hline$X$ & Bedah Kasus II & $\begin{array}{l}\text { Menjelaskan dan mendiskusikan kasus korupsi yang } \\
\text { telah diproses di persidangan sehingga mahasiswa } \\
\text { memahami bagaimana seluk beluk terjadinya perilaku } \\
\text { koruptif dalam masyarakat }\end{array}$ \\
\hline XI & $\begin{array}{l}\text { Gerakan dan } \\
\text { Kerjasama }\end{array}$ & $\begin{array}{l}\text { Menjelaskan dan mendiskusikan gerakan di tingkat } \\
\text { Internasional dalam mencegah korupsi sehingga }\end{array}$ \\
\hline
\end{tabular}




\begin{tabular}{|l|l|l|}
\hline & $\begin{array}{l}\text { Internasional } \\
\text { Pencegahan Korupsi }\end{array}$ & $\begin{array}{l}\text { mahasiswa mampu menjelaskan manfaat keikutsertaan } \\
\text { Indonesia dalam gerakan dimaksud }\end{array}$ \\
\hline \multirow{3}{*}{ XII } & $\begin{array}{l}\text { Belajar dari Negara } \\
\text { Lain dalam } \\
\text { Memberantas } \\
\text { Korupsi }\end{array}$ & $\begin{array}{l}\text { Menjelaskan dan mendiskusikan kisah sukses negara } \\
\text { lain dalam memberantas korupsi sehingga mahasiswa } \\
\text { mampu mengidentifikasi faktor keberhasilan } \\
\text { pemberantasan korupsi }\end{array}$ \\
\hline XIII & $\begin{array}{l}\text { Peran Mahasiswa } \\
\text { dalam Gerakan Anti } \\
\text { Korupsi }\end{array}$ & $\begin{array}{l}\text { Menjelaskan dan mendiskusikan peran mahasiswa } \\
\text { dalam gerakan anti korupsi di Indonesia sehingga } \\
\text { mahasiswa dapat menjadi agent of change budaya anti } \\
\text { korupsi }\end{array}$ \\
\hline XIV & UAS & \\
\hline
\end{tabular}

\section{Metode Pembelajaran}

Karena mata kuliah Pendidikan Anti Korupsi merupakan mata kuliah penanaman nilai, maka metode yang tepat untuk itu adalah proses internalisasi nilai secara integratif. Menggunakan pendekatan Teori planned behavior dari Fishbein dan Ajzen (1975), maka pendekatan yang diambil digambarkan sebagai berikut:

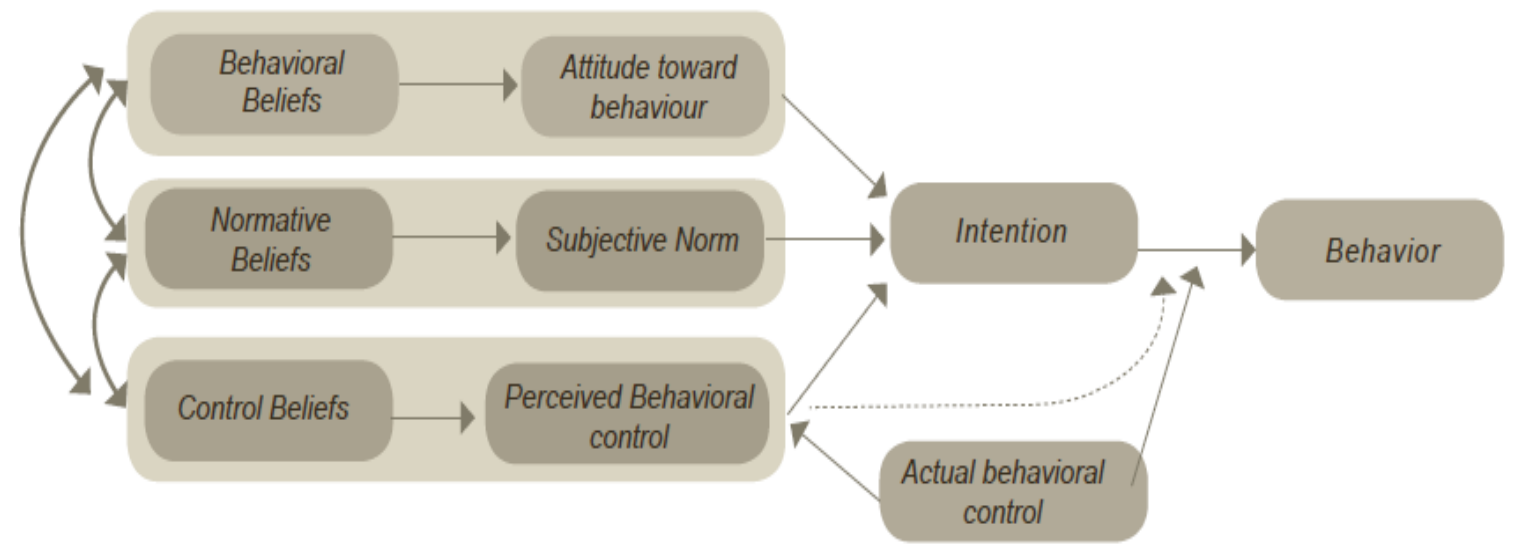

Menurut Fishbein dan Ajzen, ada tiga komponen pembentuk perilaku (1) attitude toward behavior, (2) subjective norms, dan (3) control belief. Attitude toward behavior (ATB) dipengaruhi oleh behavioral belief, yaitu evaluasi positif ataupun negatif terhadap suatu perilaku tertentu - tercermin dalam kata-kata seperti, benar-salah, setuju-tidak setuju, baik-buruk, dll. Evaluasi negatif terhadap perilaku korupsi dan evaluasi positif terhadap antikorupsi akan meningkatkan intensi (potensi) untuk berperilaku anti-korupsi. Sedangkan Subjective norms (SN) dipengaruhi oleh subjective norms di sekeliling individu yang mengharapkan si individu sebaiknya berperilaku tertentu atau tidak. Misal norma agama (bagi individu beragama), norma sosial, norma keluarga, atau ketika orang-orang yang penting bagi individu atau cenderung dipatuhi oleh individu menganggap perilaku anti-korupsi 
sebagai hal positif, maka akan meningkatkan intensi (potensi) berperilaku anti-korupsi. Control belief (CB) yang dipengaruhi oleh perceived behavior control, yaitu acuan kesulitan dan kemudahan untuk memunculkan suatu perilaku. Ini berkaitan dengan sumber dan kesempatan untuk mewujudkan perilaku tersebut. Misalnya lingkungan disekeliling individu yang korup atau kesempatan korupsi yang besar/mudah akan meningkatkan intensi individu untuk melakukan perilaku korupsi, dan sebaliknya.

Mata kuliah Anti-korupsi berfungsi untuk mempengaruhi ketiga komponen (behavioral beliefs, normative beliefs, control beliefs) tersebut secara kuat sehingga dapat menyumbang pada pembentukan attitude toward behavior, subjective norm, perceived behavioral control mahasiswa - yang selanjutnya dinamika ketiganya akan menentukan tingkat kekuatan intensi perilaku antikorupsi mahasiswa.

Idealnya perilaku anti-korupsi mahasiswa yang disasar adalah konsistensi anti-korupsi ditengah realitas lingkungan eksternal yang masih sangat korup. Konsistensi ini diharapkan selanjutnya meningkat menjadi keberanian mahasiswa menjadi garda depan dalam mengajak masyarakat untuk melakukan zero-tolerance terhadap tindak korupsi.
Selain dengan pendekatan planned behaviour di atas, pembelajaran juga menggunakan metode Pembelajaran Berpusat Siswa/Student-Centered Learning.

\section{Penutup}

Berdasarkan penjelasan di atas, maka dapat disimpulkan bahwa pencegahan dan penanggulangan korupsi dalam tataran peraturan perundang-undangan sudah cukup lengkap; mencakup tidak kurang dari 11 peraturan setingkat UndangUndang yang berevolusi dari tahun 1957 sampai dengan 2006. Evolusi di tingkat peraturan tersebut berkembang sesuai dengan dinamika sosial dan politik bangsa, sehingga beberapa keputusan politiknya sangat erat melekat pada masa yang bersangkutan dan karenanya perlu diubah pada era berikutnya.

Pemberantasan korupsi tidak cukup hanya dengan tindakan represif seperti penyelesaian hukum melalui pengadilan tindak pidana korupsi, tetapi memerlukan semua komponen bangsa terkait untuk melakukan kontribusinya dalam memberantas perilaku korupsi; dan menurut berbagai kalangan, upaya pencegahan dan penghapusan korupsi yang lebih efektif adalah yang bersifat preventif, termasuk dan terutama melalui pendidikan. Untuk dapat berfungsi secara efektif Pendidikan Anti Korupsi di Perguruan Tinggi, perlu disusun suatu materi 
pembelajaran yang terstruktur dan berkesinambungan sehingga sasaran pembentukan karakter dapat dicapai. Namun demikian, sebelum menyusun kurikulum dimaksud, perlu dielaborasi terlebih dahulu karakter atau sikap yang dapat mendukung pembentukan sikap anti korupsi.

Berbagai pendapat diusulkan sebagai karakter dasar yang harus dikuatkan untuk dapat membangun sikap anti korupsi. Namun yang paling menarik adalah mengembangkan karakter atau sikap dimaksud dari falsafah negara Indonesia: Pancasila, sebagaimana yang diusulkan oleh KPK. Dengan memahami dan menerapkan sila-sila dalam Pancasila, maka akan terbentuk karakter yang dapat membedakan hal yang benar dan yang salah (etis), karakter mampu menempatkan diri di tengah masyarakat luas (kematangan sosial, manusiawi, adil, beradab), karakter respek dan interdependensi (kerjasama, saling menghormati, demokratis), karakter mampu menempatkan kepentingan bersama di atas kepentingan pribadi (sinergis).

\section{DAFTAR PUSTAKA}

Anwary, 2012, Perang Melawan Korupsi di Indonesia - Studi Kasus Maraknya Tindak Pidana Korupsi, Penindakan dan Strategi Pemberantasannya, Institut Pengkajian Masalah-Masalah
Politik dan Sosial Ekonomi, Jakarta.

Budiningsih, C.A, Pembelajaran Moral: Berpijak pada Karakteristik Siswa dan Budayanya, Bhineka Cipta, Jakarta, 2004.

Dreher, Axel, Christos Kotsogiannis, Steve McCorriston, 2004, Corruption Around the World: Evidence from a Structural Model.

Direktorat Jenderal Pendidikan Tinggi, Kementerian Pendidikan dan Kebudayaan RI, 2011, Pendidikan Anti-Korupsi Untuk Perguruan Tinggi.

Hamzah, Andi, 2002, Pemberantasan Korupsi Ditinjau Dari Hukum Pidana, Jakarta: Penerbit Pusat Hukum Pidana Universitas Trisakti.

Hartanti, Evi, 2008, Tindak Pidana Korupsi, Jakarta: Sinar Grafika.

Indriati, Etty, 2014, Pola dan Akar Korupsi - Menghancurkan Lingkaran Setan Dosa Publik, PT Gramedia Pustaka Utama, Jakarta.

Kaligis, OC, 2008, Praktik Tebang Pilih Perkara Korupsi, PT Alumni Bandung.

Kementerian Pendidikan dan Kebudayaan RI, Direktorat Jenderal Pendidikan Tinggi, 2011, Pendidikan Anti Korupsi untuk Perguruan Tinggi.

Kompas.com, 2014, Tren Korupsi Naik Lagi, http://nasional.kompas.com/ $\mathrm{read} / 2014 / 08 / 18 / 10085091 /$ Tren.Ko rupsi.Naik.Lagi.

Kurniawan, Luthfi J dan Hesti Purspitosari, 2012, Negara, Civil Society, dan Demokratisasi, Intrans Publishing, Malang. 
Panduan Penyelenggaraan Pendidikan Anti Korupsi Di Madrasah, makalah dapat diunduh di http://www.kemenag.go.id/file/file/ ProdukHukum/ftec1380095521.pdf.

Poerwadarminta, WJS, 1976, Kamus Umum Bahasa Indonesia, Jakarta: Balai Pustaka.

Martono, Nanang, 2012, Sosiologi Perubahan Sosial - Perspektif Klasik, Modern, Posmodern, dan Poskolonial, PT RajaGrafindo Persada, Jakarta.

Montessori, Maria, Pendidikan Antikorupsi Sebagai Pendidikan Karakter Di Sekolah.

Rokhmad, Ali, Birokrasi Tanpa Korupsi, 2013, Sains Press, Sarana Komunikasi Utama Bogor.

Tim Pengkajian SKPN Badan Pengawasan Keuangan Dan Pembangunan, 2002, Upaya Pencegahan Dan Penanggulangan Korupsi Pada Pengelolaan APBN/APBD.

Kejaksaan Republik Indonesia, 2010, Tindakan Preventif Dan Represif Dalam Pemberantasan Tindak Pidana Korupsi, dapat diunduh di http://www.kejaksaan.go.id/unit_ke jaksaan.php?idu $=28 \&$ idsu $=35 \& \overline{\mathrm{id}}=$ 1546.

\section{Peraturan Perundang-Undangan}

Undang-Undang Nomor 7 Tahun 2006 Tentang Pengesahan United Nations Convention Against Corruption, 2003.

Undang-Undang Nomor 30 Tahun 2002 Tentang Komisi Pemberantasan Tindak Pidana Korupsi.
Undang-Undang Nomor 31 Tahun 1999 Tentang Pemberantasan Tindak Pidana Korupsi.

Undang-Undang Nomor 20 Tahun 2001 Tentang Perubahan Atas UU Nomor 31 Tahun 1999 Tentang Pemberantasan Tindak Pidana Korupsi.

Undang-Undang Nomor 28 Tahun 1999 Tentang Penyelenggara Negara yang Bersih dan Bebas dari Korupsi, Kolusi, dan Nepotisme.

Undang-Undang Nomor 20 Tahun 2003 Tentang Sistem Pendidikan Nasional.

Peraturan Pemerintah Nomor 19 Tahun 2005 Tentang Standar Nasional Pendidikan.

Instruksi Presiden No. 5/2004 tentang Percepatan Pemberantasan Korupsi.

Permendiknas Nomor 22 Tahun 2006 tentang Standar Isi. 